Iranian Journal of Applied Linguistics (IJAL), Vol.18, No.1, March 2015, 95-126

\title{
The Role of Verbalization in Listening Conceptual Formation among Iranian EFL Learners: A STI Perspective
}

\author{
Morvarid Lavasani ${ }^{1}$ \\ Ph.D. candidate in Applied Linguistics, Islamic Azad University, Research and \\ Science Branch, Tehran \\ *Parviz Birjandi ${ }^{2}$ \\ Professor of Applied Linguistics \\ Islamic Azad University, Research and Science Branch, Tehran
}

Received 5 September 2014; revised 17 January 2015; accepted 5 February 2015

\begin{abstract}
The present study was an attempt to investigate the significance of verbalization and teaching the concepts of listening on the development of listening performance among Iranian EFL learners. To do so, an experimental study was designed in which the participants were sixty pre-intermediate learners selected based on the results of their performance on a standard version of Oxford Placement Test (OPT).
\end{abstract}

Email address ${ }^{1}$ : mlavasani@srbiau.ac.ir

Email address' ${ }^{2}$ :pbirjand@srbiau.ac.ir

Corresponding Author: West Kabirzadeh Boulevard, South Janat Abad, Tehran 94941, IRAN English Department, College of Foreign Languages and Literature, Islamic Azad University Science and Research Branch 
The participants were divided into two experimental groups. The learners in experimental group I (Systemic Theoretical Instruction- Explanation and Materialization (STI-EM), were exposed to materialized tools which consisted of presenting the target concept in charts accompanied by the examples and related strategies to extract the concept, while Group II students (Systemic Theoretical Instruction- Explanation, Materialization, and Verbalization (STI-EMV), enjoyed materialized tools as well as collaborative verbalization. The learners in both groups went through pre-test, intervention, and post-test. The collected data were analyzed through employing analysis of covariance (ANCOVA). The results indicated that the group which practiced collaborative verbalization in L1 outperformed the one which was just mediated by teacher's oral explanation and materialized objects.

Key words: Concept formation; Materialization; Collaborative verbalization; Listening performance

\section{Introduction}

Concept formation involves mental functioning mediated by artefacts such as symbols, charts, pens, and specifically language (Vygotsky, 1978). Concepts are formed as a result of interaction between human experiences, conscious planning, complex thinking, and mediation (Vygotsky, 1981). To Frazier (2013), when the concept formation is combined with speech or words, an appropriate situation will be provided for the learners to wonder, observe, analyze, and be aware of their own process of learning. One way of instruction that emphasizes concept formation and is recently applied to second or foreign language teaching is Systemic Theoretical Instruction (STI). It is a pedagogical model proposed by Gal'perin (1969) and originated from Vygotsky's sociocultural theory (SCT) of consciousness. Teacher's oral explanation, materialized tools, and collaborative verbalization practice constitute the major tenets of STI.

The offshoots of employing STI in teaching second and foreign languages could be traced to the works of several scholars, the most important of which are as 
follows: Negueruela (2003) applied STI to teach Spanish verbal mood, aspect, and verbal tense to English college students. Serrano-Lopez and Poehner (2008) used STI to teach Spanish locative prepositions to English university students and vanCompernolle (2012) employed it for teaching socio-pragmatic knowledge of second pronoun in French to the English learners. Lee (2012) relied on STI in teaching systematic meaning of phrasal verbs with (up, over, and out), while Kao (2014) employed it in teaching Chinese rhetoric or discourse organization in writing to L2 learners. Fogal (2015) also used STI in teaching text-based rhetorical features in writing to Japanese learners. The major findings of the aforementioned studies indicate that STI has a positive effect on the second/foreign language development.

Although the number of research on the application of STI in the English Language Teaching (ELT) is not scarce, only few research projects have focused on the role of teaching listening performance based on STI and highlighting the stage of verbalization in the empirical research. It should be noted that verbalization brings about changes from product-oriented to process-oriented approach in listening activities when learners detect, identify, and explain the target concepts to their classmates in listening tasks. Vandergrift (2007) believes that in the product-oriented approach towards listening, little is known about the reasons or processes underlying learners' performance and the only important issue is learners' success. However, in the product-oriented approach, educators have not, to date, found out enough information about the reasons behind learners' comprehension breakdown. Verbalization could be considered as an efficient tool for checking learners' understanding and drawing their attention to the related concepts in the present study. Therefore, the paucity of research on the role of verbalization in listening comprehension and listening performance has made us probe learners' listening performance by different mediational artefacts.

In the same vein, Ableeva (2010) asserts that "many recent textbooks intended to develop the L2 listening of intermediate students do not present L2 spoken features conceptually and provide minimal explanations of these features" (p.148). 
Therefore, some efforts should be made to help learners effectively understand theoretical listening concepts. The current study was an attempt to provide the EFL learners with the main spoken language concepts by applying different ways of mediational tools that might be needed in developing a good command of listening performance.

\section{Review of the Related Literature}

Regarding the salience of listening in language learning (Field, 2012; Vandergrift, 2007) and its prominence for the learners, it is central to enable L2 learners to listen effectively with the goal to bring about development in their listening performance. A review of studies focusing on L2 listening reveals that these studies have mainly focused on identifying the nature, type, and range of L2 listening strategies used by learners of higher and lower proficiency levels (Goh, 2002). Investigating the relationship between strategy use and successful listening has also been researched (Vandergrift, 1997). Later studies, meanwhile, have focused on explicit instruction of cognitive and metacognitive learning strategies to ESL learners (Cross, 2009). Since teaching listening concept formation has been neglected in most language classes (Vandergrift, 2007), it is desirable to teach scientific concepts of spoken language explicitly to develop learners' aural text comprehension.

\section{Listening Concepts}

Listening is perceived as a complex and multidimensional skill (Buck, 2003). To understand this intricate process, previous listening theories have attempted to describe listening in terms of taxonomies investigated to find out the theoretical concepts of listening as a minimal unit of instruction. Buck (2003) developed the comprehensive "framework of listening ability" model. It has two main components: a) language competence, and b) strategic competence. Language competence is defined as "the knowledge about the language that the listener brings to the listening situation which includes fully automated procedural knowledge and controlled or conscious declarative knowledge"(p. 104). The subcategories of linguistic knowledge are grammatical, discourse, pragmatic, and 
sociolinguistic knowledge. Strategic competence is defined as the ability to use language competence. It includes cognitive and metacognitive strategies. Buck associates cognitive strategies to comprehension, storing, and retrieving input, and metacognitive strategies to assessing the situation, monitoring, self--evaluation and self-testing.

Likewise, Goh (2014) classifies types of knowledge that support listening comprehension as knowledge of language, knowledge of discourse as well as language use. One aspect of language use is phonological knowledge, which facilitates perception. He added that for effective parsing, the grammatical knowledge including casual and informal speech, ellipsis, question tags, repetition, and redundancies, along with vocabulary knowledge such as being familiar with formulaic expressions, colloquial and idioms are required. Discourse knowledge and language use support learners with regulations of conversational turns, the way a lecture begins and ends, employment of discourse markers, and drawing conclusions about speaker's intentions. Following the taxonomies of listening skills, the researchers were able to develop instructional units and materialized objects respectively as mediational tools in this study.

\section{Concept Formation}

Concepts are formed through mediation of artefacts, specifically language (Frazier, 2013; Lai, 2012; Swain, 2000). To Vygotsky (1981), an interaction between subject and others, and subject's reflection is prominent in the formation of concepts. The development of scientific concepts in the school setting "begins with work on the concept's verbal definition, with operations that presuppose the nonspontaneous application of this concept" (Vygotsky, 1987, p.217). He further added that concept definition had a key role in the development of scientific concept; however, the ability to define concepts is considered as the initial stage of development (1986). Since in STI the scientific concepts of the specific domain are explained, the following part focuses on the differences between scientific and spontaneous concepts. 
The distinction between spontaneous and scientific concepts is at the heart of SCT educational theory (Vygotsky, 1987). Spontaneous concepts refer to practical concrete experience that one encounters daily. This kind of knowledge is gained empirically and unconsciously; therefore, its formation requires a long period of practical experience (Kozulin, 1995). However, scientific concepts refer to the information achieved based on theoretical exploration and this sort of knowledge is highly domain-specific (Karpove, 2003, as cited in Lantolf, 2012). To Vygotsky (1987), the goal of formal education is guiding students to internalize scientific concepts and apply scientific knowledge and understanding in their practical activities. Scientific knowledge supports learners with greater understanding, awareness, control, and creativity (Negueruela, 2008). Consequently, the instruction of listening scientific concept is considered necessary in developing a reliable command of listening performance (Ableeva, 2010). Since understanding scientific concepts is complex, learners require formal instruction to achieve those concepts (Talyzina, 1981). The systemic and instruction-based training, as Gal'perin (1969) discussed, is helpful in educational development. Following Gal'perin's ideas, Neguerela (2003) presented the idea of enriching second language development among the learners through presenting grammatical concepts by employing the materialized tools and verbalization.

\section{Systemic Theoretical Instruction}

Gal'perin (1989) designed a pedagogical model known as systemic-theoretical instruction (STI) and alternatively referred to it as Concept-Based Instruction (CBI). Lantolf and Throne (2006) point out that Gal'perin's pedagogical model focuses on three principles of materialization or visualization, verbalization (languaging, Swain, 2000), and internalization. In STI, the pedagogical sequences are organized around a scientific concept in a systematic form. Scientific concepts are presented verbally (speech or written), then modeled imagistically which are termed as SCOBAs (Schema for Orienting Basis of Action) or materialized objects. To Gal'perin (1989), materials are actual objects or substituted for objects such as depiction in pictures, drawings, charts, or written forms, that support mental processes. 
Verbalization or languaging refers to "producing language, and in particular, producing language in an attempt to understand -to problem solve- to make meaning"(Swain, 2006, p. 96). Verbalization in the form of oral or written explanation of the concepts leads learners to monitor and evaluate their actions (Frazier, 2013; Negueruela, 2003) while working on related tasks. It also helps learners to externalize their understanding of the concepts and is considered as the next phase after materialization in STI. Verbalization guides learners to regulate the process of development (Lantolf \& Poehner, 2008) through conscious inspections. Speech is accepted to mediate thought and this may occur by different ways such as collaborative speech among learners (e.g., Swain \& Lapkin, 2002), speech between learner and expert (e.g., Aljaafreh \& Lantolf, 1994), or the private speech of individual learners (e.g., DiCamilla \& Anton, 2004). Speech in any form, social or individual, serves to facilitate learning and leads learners to gain selfregulation. Vygotsky (1981) asserts that through the mediation of words, a concept is understood and constructed in relation to other concepts. In Vygotskian Sociocultural Theory (SCT), the use of language (L1) provides additional cognitive support for learners in solving their L2 leaning challenges. According to Brooks and Donato (1994), speech in any form either between people or to oneself enables one to plan, coordinate, and review action.

When the learners gain mastery over the concepts through the previous stages such as materialization and verbalization, the process of internalization is formed through inner speech. As a result, internalization is not an exact copy of what is externally mediated to one's mind (internal). Lantolf and Throne (2006) argue that the process of internalization is "the constant exchange of processes between themselves and their environment" (p. 160). Consequently, internalization is an active process in which both external factors or sociocultural relations; and individual's interpretations interact for its formation. The following part covers the two recorded works in the literature pertaining to EFL learners' ability in theoretical concept formation by applying materialized tools (Carpay, 1974, cited in Lai, 2012) and verbalization as well as materialized tools (Lapkin, Swain, \& Knouzi, 2008). 
Carpay (1974, as cited in Lai, 2012) conducted a research on teaching Dutch participants to select the appropriate verbal aspect in Russian. The stages of the study were the same as Gal'pein's model. That is, the concept of aspect was explained for the learners, then visual object in the form of algorithm was presented to the learners to clarify the concept of (non-iterative vs. iterative) actions. Finally, learners had to select the most appropriate aspectual forms of the verb. The stage of verbalization was not taken into account and skipped. The success of the learners in understanding the concept of aspect was directly related to the materialized objects.

Lapkin, Swain, and Knouzi (2008) did a research on the importance of verbalization in deep understanding of the grammatical concept of French voice. Learners were provided with a coherent explanation text with 12 sentences in active, passive, and middle voice. In addition, two SCOBAs that illustrate the relation between agent and patient in the exemplar sentences were presented to the learners. Learners had to explain the highlighted verbs in the provided text and verbalize the concept. The results of the immediate posttest showed that the learners had some improvement. The qualitative analysis of students' explanation of voice showed that the incorrect understanding of the target concepts turned to the point that learners could make connection between active, passive, and middle voices and they could also make self-corrections. A delayed post-test was conducted a week later and the results showed that the learners' deep understanding of the target concepts and the researchers attributed this improvement to the verbalization practice.

The present study enjoyed an experimental design in which the learners were exposed to different mediational artefacts. One experimental group was just exposed to the teacher's oral explanation of the target concepts accompanied by materialized items (STI-EM), the same as Carpay's research. Another experimental group was exposed to the teacher's oral explanation of the target concepts, materialized tools, and verbalization practice (STI-EMV) like the procedure conducted by Lapkin, et al. (2008). 


\section{The Study}

As stated above, the primary goal of this study was to investigate the effect of (STI) on theoretical listening concept formation. This goal was realized throughout the following research questions:

1. Is there any significant difference in EFL learners' ability in theoretical listening concept formation between the two groups of mediation (STI-EM \& STI-EMV)?

2. Is there any significant relationship between concept formation and listening performance?

\section{Method}

\section{Participants}

Sixty adult undergraduate EFL students majoring in English literature and translation were selected as the participants in the study. All the participants attended a compulsory course of listening comprehension at the time of the study. Seventy one participants were selected based on convenient non-random sampling. Students' equal listening performance was one of the main considerations when deciding to select learners in this study. To ensure that the sample included only participants who had equal listening performance, those who scored one SD above and one SD below the mean in listening part of Oxford Placement Test (OPT) were included in the study. The mean obtained was 67.8 and the $S D$ was10. The 60 participants who did qualify to be included in the analysis were randomly divided into two groups: the (STI-EMV) group $(\mathrm{N}=30)$, and the (STI-EM) group $(\mathrm{N}=30)$. The differences among groups were related to the type of mediational artefacts they were exposed to during their listening instruction.

\section{Instruments}

\section{Instructional Instruments} Instructional Units

All the instructional tasks were collected and adapted from different intermediate instructional listening textbooks by the researchers in order for the learners to become acquainted with a range of tasks on real-life situations and a broad range of accents. The listening tasks were selected : (a) from the recordings of the book 
entitled REAL listening and speaking (Craven, 2008) Book 3 and 4 which correspond to (B2 \& C1) listening proficiency, (b) Interactions 1 (Tanka \& Most, 2007), (c) Interactions 2 (Tanaka \& Baker, 2004) (d) Tune in (Richards \& O'Sullivan, 2007), (e) Tactics for Listening (Developing and Expanding books by Richards, 2011), and (f) Passages (Richards \& Sandy, 2008 ). Some of the chosen listening texts were slightly above the learners' level of listening comprehension for the purpose of being sufficiently challenging for the learners. The listening practice tasks were identical for the two groups, and each instructional unit was accompanied by a mediational sheet of materialized form of concepts (see Appendix).

\section{Verbalization}

Since one of the conditions for developing mental action in Gal'perin's approach is the use of speech as a tool for concept formation, students were asked to collaboratively verbalize with their partners while accomplishing tasks in STIEMV group. Verbalization activity was carried out through both spoken and written language. The oral verbalization was practiced dyadically to support the understanding of listening concepts. Spoken form incorporated learners' overt speech to another (their partner in the class for two tasks in each concept). They had to explain their understanding about the related rules that contributed to successful accomplishment of the task. All their explanations about the target concept were audio-recorded by themselves, and a learner was randomly asked to play the audio-recorded speech for the whole class. Then, the other students listened and commented on their classmates' descriptions.

For more illustration, a sample of oral verbalization from the stress section is presented. The learners were exposed to a written text and had to underline the words that would take the greatest stress. Then, they had to talk to their partners to justify their answers by referring to the materialized form of rules which was explained by the teacher. Finally, they had to listen to the aural text to check their answer. Transcribed of two learners' verbalization in STI-EMV group was:

A: I think the words "agree, deal", and "lose control" take the most stress because all of them convey the most important piece of information. 
B: Exactly, because the words "agree and lose control" are verbs, and "deal" is a noun. They are content words. But I think we also have to underline the word "company" in line 1. It is important, too.

A: May be, but I think this word is not that much important.

$B$ : I think it is and I underline it.

Moreover, the learners were provided with listening homework which were selected and adapted from the above-mentioned instructional books by the researchers for each specific concept (only the STI-EMV group practiced this written form of verbalization). On a separate sheet of paper, students in STI-EMV group had to write their explanations and reasons. All the written verbalizations were collected for further analysis by the researchers for the next session. This activity was carried out without writing their explanation for the STI-MI group.

\section{Measurement Instruments}

\section{A Placement Listening Test}

The standard Oxford Placement Test (OPT) listening part was used for selecting and screening the participants. OPT was only used for the initial selection of the 60 participants of the study out of 71 based on the \pm 1 standard deviation above and below the mean. In the current study, the estimate of reliability for the test was 0.72 as estimated by Cronbach's Alpha.

\section{Concept Definition Assessment Tool}

To investigate the development of listening concept understanding and learners' ability to define them, a pretest and posttest of listening concepts were carried out through employing concept definition assessment tool. Since concept definition is so demanding for the participants, some audio examples associated with each concept were selected from the pool of listening tasks in different instructional books by the researchers and checked by the rater who was a professional language teacher and a $\mathrm{PhD}$ candidate. By listening to these recorded examples, learners' understanding abilities in defining concepts were elicited. They had to answer concept-related questions, then write the name of that specific concept, and finally define it fully in L1 (Persian). An example of one of the concept questions 
regarding stressed words adopted from the Real Listening and Speaking Book 4 (Craven, 2008) follows:

Audio recording: A short conversation

Woman: Okay, so I pay in advance, you will give me a $10 \%$ discount?

Man: Yes, and if you pay now, then I will give you a $\underline{15 \% \text { discount. }}$

Q1: In this recorded conversation which words have a greater significance? Write the words below and explain how you identified them.

The test comprised the following two subsets of listening comprehension: a multiple-choice format with 3 items, and questions and answers format with 10 items designed for administration within a period of 45 minutes. The whole test comprised 8 aural texts of three different genres including three short conversations, three monologs, and two mini-lectures. Table 1 provides a detailed description of the listening concept definition test structure for pre-test.

\section{Table 1}

Details of Listening Concept Definition Pre-Test Items

\begin{tabular}{|c|c|c|c|c|c|}
\hline Test format & Concepts & Items & Accent & Text type & Length \\
\hline Question/ written form & $\begin{array}{l}\text { Stress/ } \\
\text { key words (sentence stress) } \\
\text { word stress }\end{array}$ & 1,11 & Australian & Conversation & $\begin{array}{ll}15^{\prime \prime} & \& \\
10^{\prime \prime} & \end{array}$ \\
\hline Question/ written form & $\begin{array}{l}\text { Grammar } \\
\text { Gap-filers } \\
\text { Ellipsis }\end{array}$ & 2,10 & American & Conversation & $\begin{array}{l}30^{\prime \prime} \\
\& 25^{\prime \prime} \\
17^{\prime \prime}, 17^{\prime \prime}\end{array}$ \\
\hline Multiple choice question & $\begin{array}{l}\text { Pragmatics/ } \\
\text { appropriate language } \\
\text { implied meaning }\end{array}$ & $3,5,9$ & $\begin{array}{l}\text { British \& } \\
\text { American }\end{array}$ & $\begin{array}{l}\text { Monologue \& } \\
\text { Conversation }\end{array}$ & $\& 2: 30 "$ \\
\hline Question/ written form & $\begin{array}{l}\text { Intonation / } \\
\text { yes or no questions } \\
\text { tag questions } \\
\text { feeling }\end{array}$ & $4,7,8$ & British & Monologue & $\begin{array}{l}22 ", \\
18 " \& \\
13^{\prime \prime}\end{array}$ \\
\hline Question/ written form & $\begin{array}{l}\text { Discourse } \\
\text { Discourse markers }\end{array}$ & $\begin{array}{l}6 \quad \text { (three } \\
\text { parts) }\end{array}$ & British & Mini-lecture & $45^{\prime \prime}$ \\
\hline
\end{tabular}




\begin{tabular}{|c|c|c|c|c|c|}
\hline Question/ written form & $\begin{array}{l}\text { Vocabulary / } \\
\text { Guessing from context }\end{array}$ & $\begin{array}{l}12 \text { (two } \\
\text { parts) }\end{array}$ & American & Mini- lecture & $2: 20 "$ \\
\hline Question/ written form & Linking & 13 & British & Monologue & $15^{\prime \prime}$ \\
\hline
\end{tabular}

The order, format, and concepts in which the subtests appeared on the posttest were exactly the same as the pretest, only the aural texts and consequently the length and accent of each aural text contrasted with pre-defined items to control testing effect.

\section{A Preliminary Test of English Listening Part}

A test of language proficiency, a Preliminary English Test (PET) listening part, was used to investigate the relationship between learners' theoretical conceptual knowledge and their listening performance. In the present study, the Cronbach alpha coefficient for pre and post-tests were 0.813 and 0.771 , respectively.

\section{Analysis}

The research design included three stages: pretest, enrichment program, and posttest. The enrichment program (EP) was designed to promote learners' conceptual understanding of features that characterize spoken English.

\section{Instructional Units and Materialized Objects}

The concepts of listening skill in this study were selected based on Buck's (2003) and Goh's (2014) listening taxonomies. Listening is considered as multidimensional and various concepts of listening such as phonological features, discourse markers, morph-syntactic structures-were practiced. As a result, the entire elements of Buck's and Goh's taxonomies for English aural text comprehension were implemented and presented systematically. Furthermore, in the study conducted by Ableeva (2010), all concepts of French spoken language such as phonological phenomena (e.g. liaison and schwa), sound fillers, discourse markers, and morphosyntactic structures were included in the enrichment program. Listening skill is measured as a package; therefore, the results concern the entire 
package, not just one concept. The main focus was raising learners' consciousness in each instructed concept. The content of the units are as follow:

1. Phonological knowledge (a) word stress (i.e., knowing different words having different syllable stress patterns in English) and sentence stress (i.e., recognizing the words carrying the most significant information and hence stress patterns and having selective attention during listening), (b) rhythm and intonation of spoken language, and (c) phonological modifications (understanding reduction, assimilation, elision, insertion, stressed and unstressed vowels),

2. Grammatical knowledge (a) understanding casual and informal way of speech in spoken language such as ellipsis, question tags, incomplete utterances, and redundancies

3. Vocabulary knowledge (a) guessing meaning from context by paying attention to context clues, and (b) understanding the great use of colloquial expressions and idioms by native speakers,

4. Discourse knowledge (a) understanding the role of turn-taking in conversation, (b) understanding different parts of a lecture such as beginning, developing, and ending, and (c) understanding the role of discourse markers,

5. Pragmatic knowledge (a) understanding the role of using appropriate responses, (b) understanding speakers' intention.

Each unit had 6 to 8 exercises to provide ample opportunity for practicing each concept. Each instructional unit was completed with a "can-do" checklist and a box for writing the items students had learned and liked regarding that unit. All the items of the "can-do" checklist were selected from Richards' (1983) classification of micro-skills in listening.

Furthermore, each instructional unit, accompanied by the mediational sheet, consisted of two parts: (a) theoretical listening concept explanation in a chart form, and (b) incomplete summaries of rules that learners had to complete after teachers' oral explanation of the concepts. This incomplete form of didactic model is labeled ISOBA (Incomplete Scheme of Orienting Basis for Action) by Talyzina (1981). She emphasized the guided-discovery role of ISOBA for the learners. At the very 
beginning of the teaching/learning process in this approach, students were provided with the means to orient themselves systematically in the subject to be studied. According to Gal'perin (1992), teachers' guidance is more effective when accompanied by symbolic and graphic representations or -Scheme of a Complete Orienting Basis of an Action- (SCOBA). Lantolf (2011) confirmed that ways of presenting scientific concepts are crucial issues for teaching scientific knowledge. In this study, the rules of listening concepts along with strategies corresponding to the concepts were included to guide the students in extracting the scientific concepts efficiently. To Buck (2003), in order to be able to use language competence, applying strategic competence is necessary (concepts \& related strategies are shown in Table 2). The linking of the concept to its related strategies was carried out by the researchers and another rater who was a professional language teacher.

Table 2

Spoken Concepts and Corresponded Strategies

\begin{tabular}{|c|c|c|c|}
\hline & $\begin{array}{l}\text { Concepts } \\
\text { Being familiar with: }\end{array}$ & Strategies to use the concepts & Unit \\
\hline 1 & $\begin{array}{l}\text { Word stress \& sentence } \\
\text { stress }\end{array}$ & $\begin{array}{l}\text { Finding the main ideas } \\
\text { Planning by having selected attention }\end{array}$ & 1 \\
\hline 2 & Intonation & Voice inferencing & 2 \\
\hline 3 & $\begin{array}{l}\text { Phonological changes } \\
\text { ( elision, blending, deleting) }\end{array}$ & $\begin{array}{l}\text { Recognition of phonological aspects of } \\
\text { fast speech }\end{array}$ & 3 \\
\hline 4 & Unfamiliar vocabulary & $\begin{array}{l}\text { Guessing the meaning of unfamiliar } \\
\text { words from the context. } \\
\text { Prediction of the topic by pre-listening } \\
\text { questions and pictures } \\
\text { Prediction of the aural text by just } \\
\text { knowing the topic } \\
\text { Prediction of the following words in } \\
\text { an aural text, in advance }\end{array}$ & 4 \\
\hline 5 & Spoken grammar & $\begin{array}{l}\text { Discrimination between spoken and } \\
\text { written grammar }\end{array}$ & 5 \\
\hline
\end{tabular}




\begin{tabular}{|c|c|c|}
\hline 6 & Pragmatics & $\begin{array}{l}\text { Making an inference based } \\
\text { interpersonal relation } \\
\text { interlocutors' intention }\end{array}$ \\
\hline 7 & Discourse markers & $\begin{array}{l}\text { Understanding the aural } \\
\text { organization } \\
\text { Note -taking } \\
\text { Summarizing information }\end{array}$ \\
\hline
\end{tabular}

It should be noted that each instructional unit focused on a single concept, but it included various topics of oral texts such as food, sightseeing, university, etc. Figure 1 indicates a part of a SCOBA for stressed words. The information about the concepts was taken from the instructional listening and speaking books such as Interactions 1 (Tanka \& Most, 2007) \& 2 (Tanka \& Baker, 2004) and Real 3\&4 (Craven, 2008).

\section{Assignment and Written Verbalization}

Since Gal'perin (1969) did not specify the mode of verbalization, the written form of verbalization was adopted for out-of-class assignments. It should be noted that Lee (2012) also used the written form of verbalization for the same purpose. The rationale for using this form of assignment was providing more opportunities for the learners to gain mastery over the concepts. To ensure that the written verbalizations for the STI-EMV were accurate, a sample of verbalization was provided and explained fully in the class by the researcher. It is worth noting that the learners did all the assignments through a cooperative mode. In addition, by taking the rules of specific concept into consideration, students had to audio-record their voice while reading the prepared dialogue. Then, they had to bring the CD of their voice samples to the class the following session. All of the assignments were in the form of prepared dialogues, except the pragmatic part in which students themselves had to make a conversation and use appropriate language by observing the relation among interlocutors (whether they were two close friends, or an employee and a boss). Some useful expressions and hints for making conversations were displayed in a table. By recording their voices, learners were encouraged to become more aware of the theoretical concepts in listening. 
These explanations (both written and oral) were carried out in learners' first language (Persian). L1 use provides learners with "additional cognitive support that allows them to analyze language and work at a higher level than would be possible if they were restricted to the sole use of L2" (Storch \& Wigglesworth, 2003, p. 760). The schematic concept formation in STI and the instruments for understanding its development are shown below (Figure 1).

\section{Concept Formation in STI}

External (applying materialized objects) Internal (learners' mind)

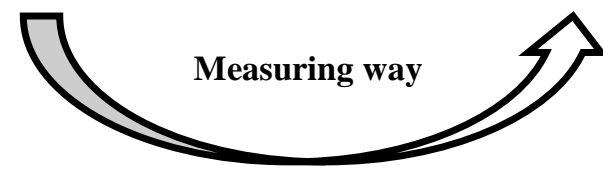

Concept definition (pre \& posttest) Taking account of instructed concepts into audio-record

Figure 1

Concept Formation in STI

\section{Scoring Procedure of Concepts}

In the concept definition part, in order to score students' answers, the learners had to answer some concept-related items, then write the concept term, and finally define the concept. A scoring method was developed that considered all the abovementioned points and each of the three parts had 0.5 mark. Each concept, except for intonation and pragmatic parts, had two items and the total score of each concept was 3 . For the pragmatic part, 3 multiple- choice items were included since finding the items related to this concept was so problematic. For the intonation part, 3 descriptive questions were selected because measuring different aspects of this concept was found in feeling, questions, and tag questions. In this part, since learners had to define all the concepts, the researcher corrected all the papers twice with a two-month interval. The intra-rater consistency was then checked by using correlational procedures. The correlation between the two ratings came out to be 
statistically significant at the 0.01 level $(\mathrm{r}=.87)$; therefore, the average score between the two ratings was computed.

\section{Procedure}

To accomplish the objectives of the present study, a pilot study preceded the main study. Ten volunteers participated in the pre-study to evaluate and give their ideas in the following areas: clarity of materialized objects (SCOBAs) and developed interventions, quantity of related tasks in each unit by excluding, adding, or segmenting some tasks, arrangement of tasks from easy to difficult in each unit, comprehensibility of instructions for each task, the required number of times for listening to audio text, length of each audio-recording and task, deciding on tasks in each unit for verbalization practice, finding the mismatches between concepts and tasks, and even the size, format, spelling, and font of writing for some tasks and concepts. The initial phase of the study took eight 2-hour sessions.

The main study lasted 13 weeks, including both concept definition as pre and post tests and the enrichment program (EP). In the first week of the study, the OPT listening part was administered to 71 participants. It took only ten minutes to complete the listening part. The test results were used to screen and select the homogenous students in terms of their listening performance. During eight enrichment sessions, the learners were given training in the target concepts which were provided with materialized objects such as charts and practicing verbalization for STI-EMV group. The EP aimed to provide instruction with respect to listening concepts. First the researcher introduced the specific spoken concept and familiarized the learners with the main characteristics of the spoken concept. Then, the corresponding strategy related to that concept was explained to learners by providing some examples. Afterwards, both instructional groups were exposed to the materialized objects. Then, some selected tasks were presented to learners in both groups. The collaborative verbalization practice for the two tasks in each unit was carried out just in one group. Since verbalization activities took more time in STI-EMV groups, the STI-EM group had extra time for watching selected movies. Each listening concept was taught in a separate session in order not to make the students confused. The instruction of discourse unit took two instructional sessions. 
In the final session, all learners took the listening concept definition test as well as the PET listening part as the posttest.

\section{Results}

\section{STI with Various Mediational Artefacts and Concept Formation}

A one-way between group analysis of covariance was conducted to determine the effectiveness of mediational artifacts on learners' listening concepts formation. The independent variable was the type of mediational artefacts (STI-EM \& STI-EMV) and the dependent variable consisted of scores on listening conceptual definition after the intervention. The participants' scores on the pre-intervention administration of listening concept definition were used as the covariate in this analysis. The assumption for running ANCOVA was checked. One assumption for running ANCOVA was the homogeneity of regression slopes. It means that the relationship between the outcome (dependent variable) and the covariate should be the same for all two experimental conditions. In order to find out the homogeneity of regression slopes, an ANCOVA was run by using a customized model. In the output obtained from the procedure, $p=.95$ which was greater than the significant value, indicated that the assumption of homogeneity of regression slopes was not violated. After checking the assumption, ANCOVA analysis was run to measure the effect of different ways of mediation on listening concept formation. The following tables show the results of Levene's test and ANCOVA.

Table 3

Levene's Test for Listening Performance Scores

\begin{tabular}{llll}
\hline F & Df1 & Df2 & Sig. \\
\hline .291 & 1 & 58 & .59 \\
\hline
\end{tabular}

The results indicated that the homogeneity of variances, the prerequisite condition for running ANCOVA, was not violated because the obtained value was greater than the alpha level of 0.05 ( $p=.59>.05)$. 
Table 4

\begin{tabular}{|c|c|c|c|c|c|c|}
\hline \multicolumn{7}{|c|}{ ANCOVA } \\
\hline Source & $\begin{array}{l}\text { Type } \\
\text { Sum } \\
\text { Squares }\end{array}$ & $\begin{array}{r}\text { III } \\
\text { of }\end{array}$ & Df & $\begin{array}{l}\text { Mean } \\
\text { Square }\end{array}$ & $\mathbf{F}$ & Sig. \\
\hline $\begin{array}{l}\text { Corrected } \\
\text { model }\end{array}$ & $200.257^{a}$ & & 2 & 100.129 & 7.270 & .0002 \\
\hline Intercept & 206.275 & & 1 & 206.275 & 14.976 & .000 \\
\hline Pretest & 147.053 & & 1 & 147.053 & 10.676 & .002 \\
\hline Group & 75.245 & & 2 & 75.245 & 5.463 & .023 \\
\hline Error & 758.101 & & 57 & 13.774 & & \\
\hline Total & 12219.375 & & 60 & & & \\
\hline $\begin{array}{l}\text { Corrected } \\
\text { total }\end{array}$ & 985.358 & & 59 & & & \\
\hline
\end{tabular}

As shown in Table 4, the results of the ANCOVA revealed that pre-test score was a significant covariate $(p: 0.002<0.005)$ meaning that the two groups significantly differed in listening concept definition scores prior to the treatment. However, after taking into account the difference prior to treatment, ANCOVA results still shows a significant difference between the post-test results of the two groups ( $p$ : $0.023<$ 0.05). It can be concluded that the performance of the two groups was not the same after receiving intervention. However, it was crucial to check the adjusted value of the groups to find the optimal way of intervention. Based on these estimates, it could be concluded that the STI-EMV group (Mean: 14.811) significantly differed from the STI-EM group (mean: 12.55). In other words, the group which practiced collaborative verbalization in L1 outperformed the one which was just mediated by teachers' oral explanation and materialized objects. The results also revealed that practicing verbalization accompanied by materialized objects significantly increased learners' understanding of listening concepts compared to merely exposing them to materialized objects. 


\section{Correlation between Concept Formation and Listening Performance}

It was expected that explicit instruction of spoken features promotes learners' deep understanding of the listening concept. This tends to correlate with learners' listening test scores. Therefore, Pearson product-moment correlation between the listening test and conceptual knowledge scores was computed. The result is indicated in Table 5 .

Table 5

Correlation between Listening Proficiency (PET) and Conceptual Knowledge

\begin{tabular}{llll}
\hline & PET posttest & $\begin{array}{l}\text { Concept definition } \\
\text { post test }\end{array}$ \\
\hline PET post-test & Pearson correlation & 1 & .63 \\
& Sig.(2-tailed) & & .000 \\
& $\mathrm{~N}$ & 60 & 60 \\
& & \\
\hline
\end{tabular}

The correlation between the two tests came out to be statistically significant at the 0.01 level $(\mathrm{r}=.63)$; therefore, it can be concluded that there was a strong positive correlation between listening theoretical concepts and listening tests.

\section{Discussion}

Data analysis confirmed that the group which practiced verbalization outperformed the group that did not practice it. In addition, there was a significant relationship between learners' ability in listening concept definition and listening performance. Regarding the impact of verbalization on conceptual understanding, the findings of this investigation were in line with the results of some previously conducted studies (Frazier, 2013; Lapkin et al. 2008; Lia, 2012; Lee, 2012; Neguerela, 2003;Van Compernolle, 2012; Yanez-Prieto, 2008). The result of all these studies showed that conceptual explanation accompanied by materialized tools and verbalization had a positive effect on language development. In the studies conducted in this area, learners' concept development was traced by the ability to define the target 
concepts (Frazier, 2013; Negueruella, 2003) as well as applying the instructed concept in their speaking (van Compernolle, 2012), writing ( Yanez-Prieto, 2008), both writing and speaking (Fogal, 2015), and translating (Kabanova, 1985, as cited in Lai, 2012). In the present study, the impact of conceptual instruction was detected both in learners' ability in defining target concepts and listening performance.

The study also supports the findings of earlier studies about the mediatory role of collaborative dialogue in L1 for language use and language learning. The role of L1 as a mediational tool for regulating behavior in the context of L2 had been previously supported (Ganem-Gutierrez, 2008, 2009; Ganem-Gutierrez \& Roehet, 2011; Harun et al. 2014; Kim \& Kellogg, 2006; Lapkin et al., 2008; Negueruela \& Lantolf, 2006; Swain, 1998).

Harun et al. (2014) carried out an investigation on the use of L1 (i.e. Malay language) as a semiotic mechanism in mediating learners' understanding of the English tense-aspect system. Data was drawn from the verbalization protocols through transcribing individual (self-explaining) and dyadic (collaborative interaction) activity during a CBI session. The findings revealed that L1 acts as a mediational tool to structure and organize thought in helping learners gain a deeper understanding of the target grammatical concept. In this research, all oral and written verbalization were carried out in Persian in a cooperative mode with the learners' classmate.

Also, the findings of the current research considered learners' listening conceptual understanding as an effective predictor of their listening performance. The findings of the study were in line with concept development in Fogal's (2015) study which was assessed by two developed rubrics across writing and speaking tasks. In Fogal's study, the instruction of text-based rhetorical concepts to Japanese learners resulted in quality improvement of learners' writing. In addition, the interview data of Yanez-Prieto's (2008) study showed that the concept-based teaching approach reconstructed students' conceptualization of the target grammatical concept. Another important finding of this study was that learners gained more ability in creating written texts by teaching Spanish aspects to English 
learners. As a result, developing conceptual knowledge of the language provided students with the power to express their own meanings through the language rather than being limited by standards and rules they had been exposed to in their earlier language learning. Also, vanCompernolle (2012) did a research on teaching sociopragmatic knowledge of second pronouns in French to English learners and reached the conclusion that learners had improvement in concept-based sociopragmatic knowledge in addition to spoken performance abilities. It should be noted that the learners' socio-pragmatic knowledge provided a systematic basis for choosing the pragmatic forms that fit learners' communicative needs.

In the present study, in STI-EM group, the major emphasis of the classroom practice was placed upon explaining the listening concepts by images and charts. Above all, teacher took the responsibility of both explaining and constructing materialized tools such as charts and images. Although in some previous studies, Kabanova (1985, cited in Lai, 2012), and Serrano-Lopez and Poehner (2008) showed that when verbalization practice was skipped from the stages of instruction, STI had a positive effect on concept development, the present study came up with different result. The findings of Kabanova's (1985) study showed that learners understood German sentence structures deeply and also could understand general principles of sentence structures of other languages. Moreover, in Serrano-Lopez's (2008) study, the results of immediate post-test indicated that groups that received STI outperformed the control group, and on the delayed post-test, the group that had done clay modeling (constructing materialized tools) outperformed the other two groups. These studies suggested that materializing tools had positive role in learning, whereas the present study showed that (STI-EM) did not improve the listening concept understanding significantly. The results of present study could be justified on the grounds that learners were exposed to prefabricated materialized tools, while in Serrano-Lopez's study, the learners themselves created the materialized tools by their own creativities. 


\section{Conclusion}

The present research was an attempt to investigate the importance of employing verbalization in the development of concept formation in listening performance among Iranian EFL learners through an STI perspective. Moreover, it highlighted the role of collaborative dialogue in L1 as a main mediational tool to regulate learners' listening concept development in comparison to materialized objects exposure. In addition, the study has also offered insights into the relationship between theoretical understanding of English listening concepts and learners' listening performance. Van Lier (2004) notes that in order to achieve the desired improvement, neither the mere amount of input nor its enhanced form suffices and it is necessary to provide learners with meaningful action. In this study, the learners' verbalization practice was considered as a meaningful action for listening tasks. By verbalization, learners' understanding of the target concepts was checked. Also, the importance of the mediating role of language (verbalization) as a pedagogical model proposed by Gal'perin (1969) was supported by the results gained from the performance of the instructional group which practiced verbalization (STI-EMV).

The main pedagogical implications of the current study are that teachers' guidance is more effective when verbalization is encouraged as part of the classroom activity in the EFL contexts, and that the effect of verbalization can be enhanced when accompanied by symbolic and graphic representations (Gal'perin, 1992) in the form of diagrams, explanatory texts, charts, images, etc. In particular, the study suggests that the material designers and language educators aiming to develop listening textbooks need to allocate some parts to present spoken language features conceptually and provide some explanations of the spoken features.

\section{Notes on Contributors:}

Morvarid Lavasani is a Ph.D. candidate at Islamic Azad University: Research and Science Branch, Tehran, Iran. Currently, she is completing her dissertation. Her research interests include instruction based on Socio-cultural Theory, learner autonomy, and teacher education. 
Parviz Birjandi professor holding a Ph.D. in English education; minor: Research methods and statistics from the University of Colorado. He has published a number of articles in the area of TEFL and is the author of English textbooks for high school and pre-university levels, five university textbooks and four practice textbooks.

\section{References}

Ableeva, R. (2010). Dynamic assessment of listening comprehension in second language learning. Unpublished $\mathrm{PhD}$ dissertation. The Pennsylvania State University. University Park, PA.

Aljaafreh, A., \& Lantolf, J. P. (1994). Negative feedback as regulation and second language learning in the zone of proximal development. The Modern Language Journal, 78, 465-483.

Brooks, F. B., \& Donato, R. (1994). Vygotskian approaches to understanding foreign language learner discourse during communicative tasks. Hispania, 77, 262 274.

Buck, G. (2003). Assessing listening. Cambridge: Cambridge University Press.

Craven, M. (2008). Real 4: Listening and speaking. Cambridge: Cambridge University Press.

Cross, J. (2009). Effects of listening strategy instruction on news video comprehension. Language Teaching Research, 13, 151-176.

DiCamilla, F. J., \& Anton, M. (2004). Private speech: A study of language for thought in the collaborative interaction of language learners. International Journal of Applied Linguistics, 14, 36-69. 
Field, J. (2012). Listening instruction. In A. Burn \& J.C. Richards (Eds.), The Cambridge guide to pedagogy and practice in second language teaching (pp. 207217). Cambridge: Cambridge University Press.

Fogal, G.G. (2015). Pedagogical stylistic and concept-based instruction: An investigation into the development of voice in the academic writing of Japanese university of English. Unpublished Ph.D. dissertation. The University of Toronto, Ontario.

Frazier, E. (2013). Concept-based teaching and Spanish modality in heritage language learners: A Vygotskyan approach. Unpublished Ph.D. dissertation. The university of Massachusetts Amherst.

Gal'perin, P. I. (1969). Stages in the development of mental acts. In M. Cole, \& I. Maltzman (Eds.), A handbook of contemporary soviet psychology (pp.249-273). New York: Basic Books.

Gal'perin, P. I. (1989) Study of the intellectual development of the child. Soviet Psychology, 27, 26-44.

Gal'perin, P. I. (1992) Stage-by-stage formation as a method of psychological investigation. Journal of Russian and East European Psychology, 30, 60-80.

Ganem-Gutierrez, A. (2008). Microgenesis, method and object: A study of collaborative activity in a Spanish as a foreign language classroom. Applied Linguistics, 29(1), 120-148.

Ganem-Gutierrez, A. (2009). Repetition, use of L1, and reading aloud as meditational mechanisms during collaborative activity at the computer. Computer Assisted Language Learning, 22(4), 323- 348.

Ganem- Gutierrez, A., \& Roehr, K. (2011). Use of L1, metalanguage, and discourse markers: L2 learners' regulation during individual task performance. International Journal of Applied Linguistics, 21, 297-318. 
Goh, C. (2002). Exploring listening comprehension tactics and their interaction patterns.System, 30, 185-206.

Goh, C. (2014). Second language listening comprehension: Process and pedagogy. In M. Celce-Murcia, D.M.Brinton, \& M.A.Snow (Eds.), Teaching English as a second or foreign language (pp. 72-89). Boston: Natural Geographic Learning.

Harun, H, Massari, N., \& Behak, F. P. (2014). Use of L1 as a mediational tool for understanding tense/ aspect marking in English: An application of concept- based instruction. Procedia- Social and Behavioral Sciences, 134, 134-139.

Kao, Y. (2014). Vygotsky's theory of instruction and assessment: The implications of foreign language education. Unpublished Ph.D. dissertation. The Pennsylvania State University. University Park, PA.

Kim. Y., \& Kellogg. D. (2006). Rules out of roles: Differences in play language and their developmental significance. Applied Linguistics, 28,2545 .

Kozulin, A. (1995). The learning process: Vygotsky's theory in the mirror of its interpretations. School Psychology International, 16, 117-29.

Lai, W. (2012). Concept-based foreign language pedagogy: Teaching the Chinese temporal system. Unpublished Ph.D. dissertation. The Pennsylvania State University, Park, PA.

Lantolf, J. P. (2011). The sociocultural approach to second language acquisition. In D. Atkinson (Ed.), Alternative approaches to SLA (pp.24-48). Routledge.

Lantolf, J. P. (2012). Integrating sociocultural theory and cognitive linguistics in the second language classroom. In E. Hinkel (Ed), Handbook of research in second language teaching and learning $2^{\text {nd }} e d$ (pp.303-318). Routledge. 
Lantolf, J. P., \& Throne, S. L. (2006). Sociocultural theory and the genesis of second language development. Oxford: Oxford University Press.

Lantolf, J. P., \& Poehner, M. (2008). Introduction to sociocultural theory and teaching of second languages. In J.P. Lantolf, \& M.E. Poehner (Eds.), Sociocultural theory and teaching of second languages (pp.1-32). UK: Equinox Pub.

Lapkin, S., Swain, M., \& Knouzi, I. (2008). French as a second language: university students learn the grammatical concept of voice. In J. P. Lantolf, \& M. E. Poehner (Eds.), Sociocultural theory and the teaching of second languages (pp. 228-255). London: Equinox Publishing Ltd.

Lee, H. (2012). A concept-based approach to second language teaching and learning: Cognitive linguistics-inspired instruction of English phrasal verbs.

Ph.D. dissertation. The Pennsylvania State University. University Park, PA.

Negueruela, E. (2003). A sociocultural approach to the teaching and learning of second languages: Systemic-theoretical instruction and L2 development. Ph.D. dissertation, The Pennsylvania State University. University Park, PA.

Negueruela. E. (2008). Revolutionary pedagogies: learning that leads to second language development. In J. Lantolf, \& M. Poehner (Eds.), Sociocultural theory and the teaching of second languages (pp.189-227). UK: Equinox Publishing.

Negueruela, E., \& Lantolf J.P. (2006). Concept-based pedagogy and the acquisition of L2 Spanish. In R. M. Salaberry, \& B. A. Lafford (Eds.), The art of teaching Spanish: Second language acquisition from research to praxis (pp. 79-102). Washington:Georgetown University Press.

Richards. J. C. (1983). Listening, comprehension: Approach, design, procedure. TESOL Quarterly, 17, 219- 240. 
Richards, J. C. (2011). Tactics for listening Expanding \& Developing (3r edition). Oxford: Oxford University Press.

Richards, J. C., \& O'Sullivan, K. (2007). Tune in: Learning English through listening. Oxford: Oxford University Press.

Richards, J. C., \& Sandy, C. (2008). Passages1(2 edition). Cambridge: Cambridge University Press.

Serrano-Lopez, M., \& Poehner, M. (2008). Materializing Linguistic Concepts through 3- D Clay Modeling: A Tool-and-result Approach to Mediating L2 Spanish Development. In J. P. Lantolf, \& M. E. Poehner (Eds.). Sociocultural theory and the teaching of second languages (pp. 321- 346). London, England: Equinox Publishing Ltd.

Storch, N., \& Wigglesworth, G. (2003). Is there a role for the use of the L1 in an L2 setting? TESOL Quarterly, 37(4), 760-770.

Swain, M. (1998). Focus on form through conscious reflection. In C. Doughty \& J. Williams (Eds.), Focus on form in classroom second language acquisition (pp. 6481). Cambridge: Cambridge University Press.

Swain, M. (2000). The output hypotheses and beyond: Mediating acquisition through collaborative dialogue. In J.P. Lantolf (Ed.). Sociocultural theory and second language learning (97-114). Oxford: Oxford University Press.

Swain, M. (2006). Languaging agency and collaboration in advanced second language proficiency. In H. Byrnes (Ed.), Advanced language learning: The contribution of Halliday and Vygotsky (pp. 95-108). London: Continuum.

Swain, M., \& Lapkin, S. (2002). Talking it through: Two French immersion learners' response to reformulation. International Journal of Educational Research, 37, 285-304. 
Talyzina, N. F. (1981). Psychology and the learning process. Moscow: Progress Press.

Tanka, J., \& Baker, L. R. (2004). Interactions2: listening and speaking (4th edition). Singapore: McGraw-Hill.

Tanka, J., \& Most, P. (2007). Interactions 1: Listening and speaking (silver edition).Singapore: McGraw-Hill.

Van Compernolle, R., A. (2012). Developing second language sociopragmatic knowledge through concept-based instruction: A mictrogenetic case study. Journal of pragmatics, 43, 3267-3283.

Vandergrift, L. (1997). The Cinderella of communication strategies: Receptive strategies in interactive listening. The Modern Language Journal, 81, 494-505.

Vandergrift, L. (2007). Recent developments in second and foreign language listening comprehension research. Language Teaching, 40, 191-210.

Van Lier, (2004). The ecology and semiotics of language learning: A sociocultural perspective. Boston: Kluwer Academic Publishers.

Vygotsky, L. (1978). Mind in society: The development of higher psychological processes. Cambridge: Harvard University Press.

Vygotsky, L. (1986). Thought and language. Cambridge, MA: The Massachusetts institute of technology.

Vygotsky L. S. (1981). The genesis of higher mental functions. In Wertsch J. V. (Ed. \& Trans.), The concept of activity in Soviet psychology (pp. 144-188).

Armonk, NY: M. E. Sharpe.

Vygotsky, L. (1987). Thinking and speech. In R.W. Rieber \& A.S. Carton (Eds.), 
The collected works of L.S. Vygotsky, Volume 1: Problems of general psychology, (Trans. N. Minick) (39-285). NewYork: Plenum.

Yanez-Prieto, C. M. (2008). On literature and the secret art of invisible words: Teaching literature through language. Unpublished doctoral dissertation. The Pennsylvania State University, PA. 


\section{Appendix}

A sample of stressed words SCOBA

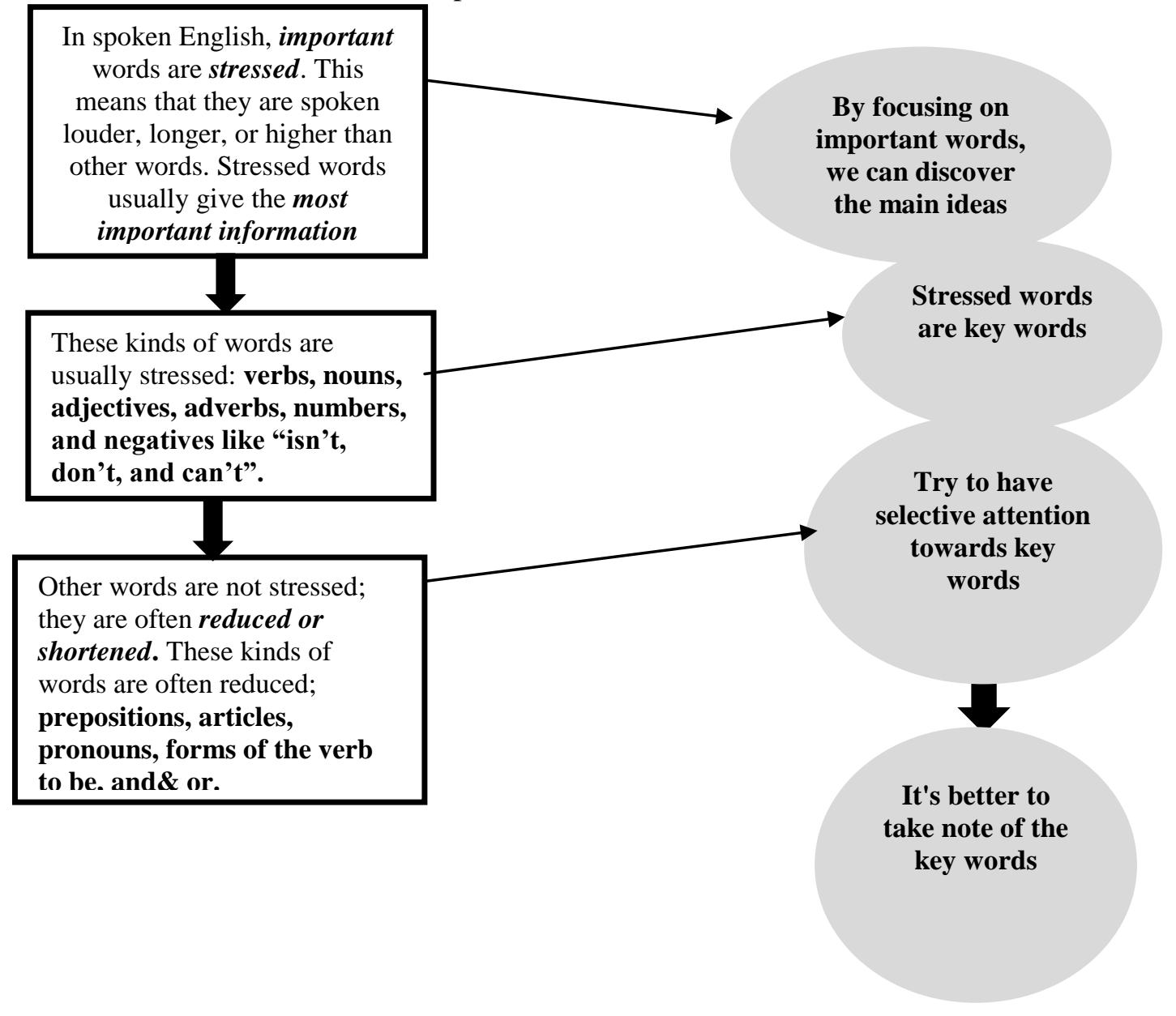

